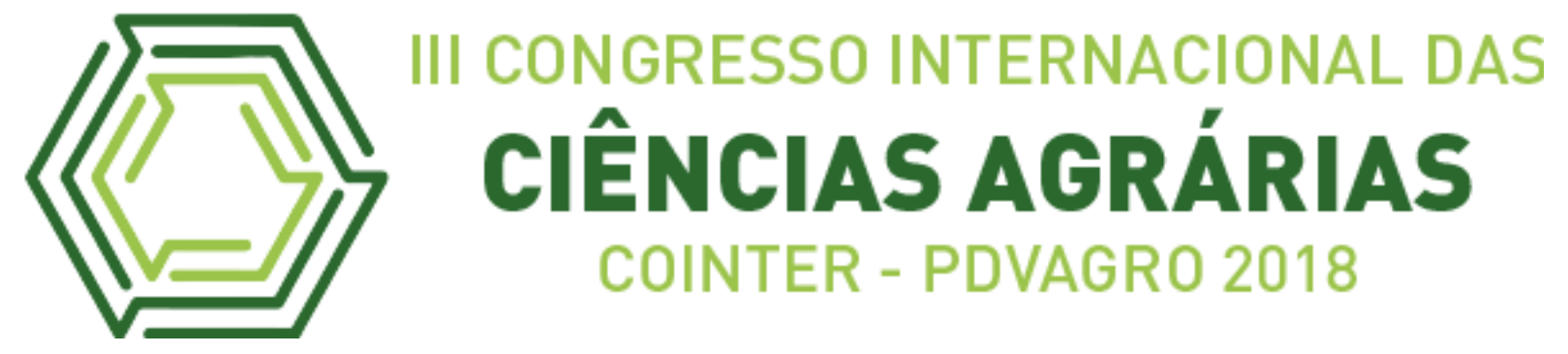

\title{
RELATO DE EXPERIÊNCIA: ACEITAÇ̃̃O DA CARNE SUÍNA PELA POPULAÇÃO DO MUNICÍPIO DE VITÓRIA DE SANTO ANTÃO - PE
}

\section{EXPERIMENTAL REPORT: ACCEPTANCE OF SWINE MEAT BY THE POPULATION OF THE MUNICIPALITY OF VITÓRIA DE SANTO ANTÃO - PE}

\author{
Apresentação: Relato de Experiência
}

Letícia Gabriele Silva de Santana ${ }^{1}$;Djalma Vitorino Costa Filho ${ }^{2}$

\section{DOI: https://doi.org/10.31692/2526-7701.IIICOINTERPDVAGRO.2018.00774}

\section{Introdução}

O Brasil é o $4^{\circ}$ país no mundo em tamanho do rebanho de suíno, ficando atrás da China, União Europeia e dos Estados Unidos (USDA, 2017). Em 2017, a criação de suínos no Brasil foi de 39.167.143 animais, sendo Pernambuco contribuindo com 261.088 cabeças nas suas diferentes mesorregiões (IBGE, 2017).

A carne suína é considerada uma carne magra, com teores baixos de gordura e calorias comparando com outras carnes e muitos cortes possuem menos gordura do que uma coxa de frango sem pele (PEREIRA et al., 2006). Mesmo com essas características, o consumidor brasileiro preferem as carnes de aves e bovinas, mesmo a carne suína sendo a mais consumida no mundo (USDA, 2017).

Com toda tecnologia utilizada na cadeia produtiva da suinocultura brasileira para assegurar sua quantidade e qualidade, ainda perduram inúmeras restrições por parte da população ao consumo da carne suína, estando eles associados a informações errôneas e "mitos" tradicionais dos processos produtivos e ambientais deste produto (SARCINELLI, 2007; DIAS, 2011). Diante disso, o objetivo deste trabalho é caracterizar o consumo da carne suína no Município de Vitória de Santo Antão.

\section{Relato de Experiência}

O presente trabalho faz parte das experiências do Projeto de Extensão realizado no Município de Vitória de Santo Antão, Pernambuco. O estudante do curso Técnico em Agropecuária do IFPE campus Vitória de Santo Antão envolvido coletou a opinião dos consumidores de carne suína no Município de Vitória de Santo Antão através de um questionário aplicado em feira livre, onde os mesmos relataram sobre os fatores que os consideravam essenciais para o consumo ou não da carne suína, sua frequência, ocasião e local.

Para essa coleta de dados foi utilizado um questionário para um total de 100 pessoas de modo

\footnotetext{
${ }^{1}$ Técnico em Agropecuária, IFPE Campus Vitória de Santo Antão, leticiagabrielessilva@ gmail.com

${ }^{2}$ Tecnólogo em Alimentos, IFPE Campus Vitória de Santo Antão, djalma.vitorino@ vitoria.ifpe.edu.br
} 
aleatório, tanto do sexo masculino como feminino, buscando uma homogeneidade nos dados. Desta forma foram entrevistados os que consumiam e os que não consumiam a carne suína, visando uma caracterização do perfil do consumidor do município e o nível de conhecimento quanto ao produto. Aos que não consumiam esse tipo de proteína animal, eram questionados por quais motivos o não consumo e se os mesmos apresentavam algum conhecimento sobre a qualidade nutricional da carne.

O município apresenta uma ampla brecha a ser completada em termos de conhecimento sobre consumidor em relação à carne suína, pois a muitas duvidas sobre a qualidade nutricional e sanitária da carne in natura. Essa situação interfere na frequência do consumo que é baixa no local, vale salientar que o consumo da carne suína envolve alguns "mitos" ou inverdades, tais como a mesma apresentar algo teor de colesterol e risco de contaminação por doença. A divulgação de informações erradas e a não busca de informações por parte da população contribui para a não ampliação do consumo pelos brasileiros, assim originam preconceitos sobre a mesma. A carne suína comercializada atualmente apresenta um teor de gordura bem menor do que a comercializada no passado, resultado do melhoramento genético das raças e a conversão dos alimentos em carne e não em gordura.

Ao verificar os fatores que causam a demando do produto, fica claro que a apresentação da carne suína é importante e que o consumidor sabe identificar a carne de boa qualidade. Fica a cabo de o setor industrial ofertar um produto de maneira variada, trazendo diferentes cortes para que o consumidor tome conhecimento da gama de produtos que são oriundos do suíno.

Esse trabalho demonstrou que os prováveis consumidores ainda necessitam de mais informações sobre o consumo da carne suína, pois se verifica muitas dúvidas sobre a qualidade nutricional e sanitária da carne in natura. Essa situação permite uma interferência no consumo que é baixa no município, vale salientar que o consumidor ainda vê o suíno como um animal de carne gorda e criado na lama, sem enxergar que essa imagem mudou.

\section{Considerações}

A cadeia suinícola avançou nos últimos anos, porém boa parte dos consumidores ainda não tem conhecimento sobre as mudanças. Dessa forma, a exposição da qualidade nutricional da carne suína pode ser explorada para o aumento da demanda da proteína animal. Nesse contexto, ressalta-se a importância de divulgação de marketing ao consumidor, já que o desconhecimento deste favorece o antigo preconceito que prevalece ainda.

\section{Referências}


DIAS, A. C. et al. Manual Brasileiro de Boas Práticas Agropecuárias na Produção de suínos. Elaboração de Conteúdo Técnico. Brasília, DF: ABCS. Concórdia: Embrapa Suínos e Aves, 2011. 140 p.

IBGE. Censo Agropecuário. 2017. Disponível em: https://sidra.ibge.gov.br/tabela/6721\#resultado. Acessado em: 26 out 2018.

PEREIRA, M. A. V. C. et al. Prevalência da Cisticercose em Carcaças de Bovinos Abatidos em Matadouros - Frigoríficos do Estado do Rio de Janeiro Submetidos ao Controle do Serviço de Inspeção Federal (SIF-RJ), no Período de 1997 a 2003. Arq. Inst. Biol., São Paulo, vol. 73, nº 1, p. 83 $-87,2006$.

SARCINELLI, M. F. et al. Características da Carne Suína. Universidade Federal do Espírito Santo UFES. Boletim Técnico: 0097. 